\title{
SLOVAK TROOPS IN ITALY DURING SECOND WORD WAR
}

\author{
Juraj ŠIMKO
}

\author{
Armed Forces Academy of General Milan Rastislav Štefánik, Liptovský Mikuláš, \\ Slovakia \\ juraj.simko@aos.sk
}

\begin{abstract}
This article deals with activities of Slovak military troops in Italy during the World War II in the period from October 1943 to the end of war. Article describes the construction of field fortifications on the German defensive lines in central and northern Italy.

As well it describes the appearance of resistance to the alliance with Nazi Germany, the involvement of the Slovaks in Italian resistance and the culmination of the fight against Nazism. The resulting manifestation was the creation of the 1st Czechoslovak division in Italy, which fought against German troops alongside the Allies at the end of the war.
\end{abstract}

\section{Keywords: Second world war, Slovak troops, Italy, defense lines, resistance}

\section{Introduction}

The history of the Slovak nation is rich. However, Slovakia is a small country and therefore its history was often influenced by larger political entities. For its history is valid, that the small and weak states become a politician tool or even the victims of the other strong and more powerful states [1]. The fate of Slovakia and Slovaks in World War II is the proof of the idea.

The theme of activities of the Slovak troops in Italy during the World War II is nearly unknown even in Slovakia, not to mention abroad. Nobody has ever analysed the impact of the Slovak troops and their operations in Italy before, except for the Slovak historian Václav Štefanský. This article is the first attempt to acquaint the foreign community with the aforementioned topic, since it brings the closer look at the elementary facts describing the activities of the Slovaks in Italy since 1943 to 1945.

The methodology that was used to prepare the material involved the research of the archival material of Military Historical
Archive Bratislava, the interviews and correspondence with the living participants of the mentioned events, as well as the analysis and synthesis of the small amount of the accessible primary sources.

In March 1939 Slovakia became an ally of Nazi Germany and its armed forces participated in the attack against Poland (1939) and in 1941 also against the Soviet Union. However, since 1942 Slovak troops started to be perceived as unreliable by German Command due to growing sentiment against war and German as well due to multiplied cases of desertions to the enemy and cooperation with local Soviet guerrilla groups In autumn 1943 by the order of German Command the $2^{\text {nd }}$ Slovak Infantry Division was changed to Technical Brigade and sent to Italy.

\section{New role of Slovak troops in Italy In October 1943, a Technical Brigade was transported along the route Minsk - Warshaw - Gorlitz - Munich - Brenner to the area of Imola - Ravenna - Cervia.}


The Technical Brigade (TB) started its activities on October 25, 1943 under the command of Lt./Col. Krnáč. It became tulle non-combat unit and should have been used by German Army Group C as a single unit under the Slovak command. The task was to build fortifications - trenches, foxholes, fire positions - along the Adriatic coast that should have served the German defense. The brigade was subordinated to the German $90^{\text {th }}$ Mechanized Division and since November 28, 1943 to the $362^{\text {nd }}$ Infantry Division. In case of attack of the Allies amphibious landings the TB should have been immediately withdrawn as a noncombat unit to the back [2].

The first dislocation zone of the TB's infantry regiments was the area of RavennaCervia. In December 1, 1943 the command of the TB was taken over by Col. Ladislav Bodický.

The Technical Brigade in Italy consisted of two Infantry Regiments - the $101^{\text {st }}$ and $102^{\text {nd }}$ Infantry Regiment. Each regiment was divided into three battalions, each battalion consisted of three companies. Furthermore, the TB was formed by: Staff Autocolumn, Cargo Truck Column, Field Bakery, Field Slaughter, Field Hospital, Field Post Office and the $12^{\text {th }}$ Railway Construction Company and Antiaircraft Battery which was returned back to Slovakia in the beginning of 1944 due to the lack of weapons and other materials. The number of soldiers accounted for about 3000 .

The TB suffered initial losses in Ravenna after bomb attack carried by the Allies on 30 December. 23 Slovak soldiers died and 19 were injured. Dead men were burried at the cemetery in Faenza.

In November and December 1943 Technical Brigade was focused on adaptation to the new area of operations and apprised new tasks on less vulnerable areas of the German defense system in Italy. The German defense strategy relied on fortified lines across Italian peninsula. The Allies that were marching from the South had to overcome these obstacles, which always required a lot of losses, and therefore their advance was incredibly slow. German defenders managed to hold back the progress of the Allies line until the next rear positions was prepared.

From In January 11, 1944 the TB was transferred to the more endangered front area. Its task was to construct lines called Orange line, Hitler's line and Dora line. The lines created the second defensive zone of the main defense line situated in the South of Rome called Gustav's line, which was aimed to protect the Liri River Valley. Slovak units were located just $20 \mathrm{~km}$ far from the main battle line. TS's units were deployed in the area of Pico - Fondi - Itri.

Slovak soldiers found themselves in front nearby zone. The assigned work sections was under the Allied air force attack almost on daily basis. Despite the problems with supply and accommodation, commander of the German engineering units in Italy Lieutenant general Hildemann evaluated the performance of Slovak soldiers as above the average, after visiting the TB work sections [3]. January and February 1944 were the most difficult periods of Slovak operation in Italy. Poor supply conditions, cold weather, and frequent Allied air attacks on the TB positions, caused the soldiers heavy strain. Some soldiers were killed or injuried by strafing. There have also been cases of refusal to start work.

Slovak Prime Minister Tuka, asked the German Command to transfer the TB to less dangerous area of the front line. However, the brigade was transferred just after German decision to use the TB in another area of the front line.

At the beginning of March 1944, the brigade was moved up to a new sector. A new task was to build the positions of Caesar's line in the Abruzzo Mountains near the towns Tagliacozzo and Avezzano [4]. There were bad roads and sidewalks in this area were wretched. All the materials had to be carried by troops or donkeys. Slovak soldiers had to dig trenches, build firing 
positions and concrete casemates that were armed with tank turrets. The soil was hard and rocky. The soldiers were exhausted, as they worked seven days a week from the beginning of 1944. Supply of food and building material was deficient. Just a few men came from Slovakia as reinforcements. Morale in the unit degraded while the Slovaks were building the lines without German advisors.

Some Slovak commanders ignored the construction plans. For example, Captain Hujsa, commander of $\mathrm{I} / 101$ (the first battalion of 101st inf. Regiment) moved spacers pins into the soft soil to make the work for soldiers easier. German Command discovered the "mistake" and assigned Slovaks their own advisors. Slovak modern historians call it "the pin case".

On June 4, 1944 the TB Headquarter received command to move to the Gothic Line (the Germans also called it Grünstellung) that was stretched from Pesaro on the Adriatic coast to Viareggio in the Ligurian Sea.

$400 \mathrm{~km}$ retreat lasted until June 20. The TB was under attack of the Allied air forces. During the retreat it suffered heavy losses. The $101^{\text {st }}$ inf. Regiment reported 61 missing, $102^{\text {nd }}$ inf. Regiment reported 8 dead, 20 wounded and 144 missing soldiers [5]. Many of the missing soldiers deserted to the Allies or Italian partisans.

When transfer to the Gothic Line was finished, the TB was subordinated to the staff of German general Bessel, who commanded the construction of fortifications in Italy. German engineers were assigned to collaborate with the brigade. Work on building the fortified Gothic line lasted until beginning of August. They included the construction of firing positions for machine guns, mortars and artillery.

In July 1, 1944 the Technical Brigade was renamed to the $2^{\text {nd }}$ Technical Division $\left(2^{\text {nd }}\right.$ TD). On July 6, 1944 Colonel Imro became the new commander, who replaced Colonel Bodický.
In early August 1944 the division started the retreat to river Po. The situation was complicated due to losses, desertion (which became more frequent from late of June) and an insufficient reinforcements from Slovakia. The declining morale in the division was proved by the fact that the new commander col. Imro fled to the Allies during the retreat. Lt./Col. Kmicikievič temporarily took command of the $2^{\text {nd }}$ TD. He commanded the division until August 25, 1944, when the command was taken over by colonel. Veselý. On September 1, 1944 the $2^{\text {nd }}$ TD had following numbers: $101^{\text {st }}$ inf. Regiment: 23 officers, 23 noncommissioned officers, 1060 men $102^{\text {nd }}$ inf. Regiment: 28 officers, 11 noncommissioned officers, 1128 men [6]. From October 24 to November 21, 1944 Slovak soldiers were working in the area of Ostiglia (situated $50 \mathrm{~km}$ west of Rovigo) and Borgoforte. The $101^{\text {st }}$ Regiment constructed the connecting path in Ostiglia in Cooperation with German Engineer Battalion no. 7. while the 102nd Regiment constructed the bridge in Borgoforte.

On November 21, 1944, the division moved into the area of Pavia in order to build and repair railways and bridges over the River Po. The division remained in this zone until the surrender of German troops in Italy (May 2, 1945).

Division ability to realize their assigned tasks had been constantly declining. Soldiers worked inconsistently. A lot of them collaborated with the Italian resistance and several dozen soldiers deserted to the Italian partisans. Division commander Col. Veselý was not able to prevent desertions.

In mid-February 1945 reinforcements, that consisted of 3000 men, came from Slovakia. The number of division members increased to 7000. They were quickly mobilized reservists and prisoners of the rebel army (The $1^{\text {st }}$ Czechoslovak Army in Slovakia - resistance army of the Slovak National Uprising). In some cases it involved former members of the $2^{\text {nd }}$ Czechoslovak Airborne Brigade in the 
USSR. Mobilized reservists didn't have a military training, not even a uniform.

Construction work had been slowed down due to the lack of material. The headquarter of the division ordered the soldiers to borrow working tools from local people and use it carefully, so they could return them undamaged after the work was finished

At workplaces of The $2^{\text {nd }}$ TD the German technical officers met with disinterest in work, Slovak soldiers inventing various excuses such as "we don't have wood, we don't have shovels, we don't have a watch" and so on. More and more members of the Division cooperated with the local Resistance and deserted to the partisans. The Headquarter of the division prescribed transfer almost every month in order to prevent "kidnapping" of soldiers from companies.

\section{Changing the side}

In April 1945 the Allies started an offensive across the River Po. In Northern Italy it mobilized the guerrilla movement and the Uprising broke out. The German army began collapsing. In the units of the $2^{\text {nd }} T D$ mass desertion began. In April 19, 1945205 men deserted from the $8^{\text {th }}$ company of the $101^{\text {st }}$ inf. Reg., and in April 25, 1945173 men from the $5^{\text {th }}$ company of the $101^{\text {st }}$ inf. Reg.

To prevent desertions to local resistance and to eliminate the threat of the Allied advance, the divisional headquarter ordered a retreat to the Alps.

However, battalion and regimental commanders did not accepted the order. Since April 24 the units of division had started to cooperate with Italian resistance or even, in some cases within their capabilities, they had been fighting against the retreating German columns. Thanks to that they took control over several villages and important crossroads.
In April 25, 1945 Slovak soldiers arrested divisional commander Colonel Veselý that was replaced by Antifascist disposed Lt./Col. Kmicikievič [7]. Kmicikievič announced to the Italian Resistance, that the Slovak division would cooperate in the fight against the Wehrmacht and therefore division had been recognized as part of the anti-nazi coalition troops. Due to the involvement in the anti-fascist resistance the name of the division was changed to the $1^{\text {st }}$ Czechoslovak Division in Italia. It consisted of 6272 men bust just one third of soldiers were active in combats as the division did not have enough weapons. In addition, many Slovaks, who previously ran from the division, fought at that time in the sections of the Italian partisans.

Operations of the Slovak soldiers against the German troops in Northern Italy continued until early May, when the first Allied units arrived to the rebels territory.

The 6th South African division, which responsibility was to supply the Slovak Division, did not receive an order that the $1^{\text {st }}$ Czechoslovak Division in Italia was considered as the Allied and handled with Slovaks as they were prisoners.

In late July 1945, Slovak units were transported to Slovakia.

\section{Conclusion}

Slovak soldiers in Italy did not have enough weapons and material for active resistance. First of all, they just sabotaged the assigned work. Several soldiers and officers deserted to the Allies or joined the Italian partisans. In the last two months of the war the division passed to the Italian resistance and one third of the team actively liberated cities and towns in Northern Italy.

In these ways, the Slovaks in Italy had been demonstrating their negative attitude towards fascism and Nazism.

\section{References}

[1] Lid'ák Ján, International relations - International politics (in Slovak: Medzinárodné vzt'ahy - Medzinárodná politika/ Bratislava, SOFA, 2000, page 27. 
[2] Military Historical Archive Bratislava (MHA), Fund ZD, sig. II/8, order from December $20^{\text {th }}, 1943$.

[3] MHA, Fund ZD, sig. I/53.

[4] Štefanský Václav, Slovak soldiers in Italy 1943 - 1945 (in Slovak: Slovenski vojaci v Taliansku 1943 - 1945), Bratislava, Ministry of Defence of Slovak Republic, 2000, page 28.

[5] MHA, Fund ZD, sig. III/9, order from june 25th ,1944.

[6] MHA, Fund ZD, sig. III/42, War diary.

[7] Štefanský Václav, Slovak soldiers in Italy 1943 - 1945 (in Slovak: Slovenski vojaci v Taliansku 1943 - 1945), Bratislava, Ministry of Defence of Slovak Republic, 2000, page 71. 